\title{
New species of Eirenidae (Hydrozoa: Leptothecata) from the Amazonian coast (northern Brazil)
}

\author{
Everton Giachini Tosetto ${ }^{1}$, Sigrid Neumann-Leitão ${ }^{1}$, Miodeli Nogueira Júnior ${ }^{2}$ \\ ${ }^{1}$ Departamento de Oceanografia, Universidade Federal de Pernambuco, Avenida Arquitetura, S/N, 50670-901, Recife, PE, \\ Brazil. \\ (EGT) (Corresponding author) E-mail: evertontosetto@ hotmail.com. ORCID iD: https://orcid.org/0000-0002-4020-0942 \\ (SN-L) E-mail: sigridnl@uol.com.br. ORCID iD: https://orcid.org/0000-0001-7878-8772 \\ ${ }^{2}$ Departamento de Sistemática e Ecologia, Universidade Federal da Paraíba, Cidade Universitária, 58051-900, João Pessoa, \\ PB, Brazil. \\ (MNJ) E-mail: miodeli@gmail.com. ORCID iD: https://orcid.org/0000-0001-5409-8312
}

\begin{abstract}
Summary: Two new Eirenidae medusae species were collected on the Amazonian coast, Eutima marajoara n. sp. and Helgicirrha angelicae $\mathrm{n}$. sp. The former differs from other species of the genus by the gonads extending along almost the entire length of the subumbrellar portion of the radial canals but not connected to the ring canal, up to 40 marginal tentacles with conical bulbs and 48 marginal warts, lateral cirri and adaxial papillae on some marginal warts and tentacular bulbs. Helgicirrha angelicae $\mathrm{n}$. $\mathrm{sp}$. differs from other species of the genus by the gonads on the middle portion of the radial canals with medusa buds, the short gastric peduncle, up to 20 marginal tentacles, some with adaxial papillae, up to three marginal warts and two statocysts between successive tentacles, and lateral cirri both on tentacle bulbs and marginal warts.
\end{abstract}

Keywords: jellyfish; Cnidaria; Hydrozoa; taxonomy; biodiversity; Atlantic Ocean; new species.

Nuevas especies de Eirenidae (Hydrozoa: Leptothecata) de la costa amazónica (norte de Brasil)

Resumen: En la costa amazónica se recolectaron dos nuevas especies de medusas Eirenidae, Eutima marajoara n. sp. y Helgicirrha angelicae n. sp. La primera se diferencia de otras especies del género por las gónadas que se extienden a lo largo de casi toda la longitud de la porción subumbrellar de los canales radiales, pero no conectados al canal circular, hasta 40 tentáculos marginales con bulbos cónicos y 48 verrugas marginales, cirros laterales y papilas adaxiales en algunas verrugas marginales y bulbos tentaculares. Helgicirrha angelicae n. sp. se diferencia de otras especies del género por las gónadas en la porción media de los canales radiales con yemas de medusa, pedúnculo gástrico corto, hasta 20 tentáculos marginales, algunos con papilas adaxiales, hasta tres verrugas marginales y dos estatocistos entre tentáculos sucesivos, lateral cirros tanto en bulbos de tentáculos como en verrugas marginales.

Palabras clave: medusa; Cnidaria; hidrozoos; taxonomia; biodiversidad; océano Atlántico; especies nuevas.

Citation/Como citar este artículo: Tosetto E.G., Neumann-Leitão S., Nogueira Júnior, M. 2020. New species of Eirenidae (Hydrozoa: Leptothecata) from the Amazonian coast (northern Brazil). Sci. Mar. 84(4): 421-430. https://doi.org/10.3989/ scimar.05051.14A

LSID: urn:1sid:zoobank.org:pub:2CABF289-3032-4718-851D-4CEC6263AC9F

Editor: D. Lindsay.

Received: March 16, 2020. Accepted: September 20, 2020. Published: October 27, 2020.

Copyright: (C) 2020 CSIC. This is an open-access article distributed under the terms of the Creative Commons Attribution 4.0 International (CC BY 4.0) License.

\section{INTRODUCTION}

Hydromedusae from the family Eirenidae Haeckel, 1879 are easily distinguished from other Leptothecata by the presence of a distinct gastric peduncle and closed statocysts (Bouillon et al. 2006). In some
Eirenidae genera there are eight statocysts (rarely 12) while in others there are an indefinite number, but always more than eight in adult medusae (Bouillon 1984, 1999, Bouillon et al. 2006). Among those with eight statocysts, Eutima McCrady, 1859 differs from Eugymnanthea Palombi, 1936 by the adult medusae 


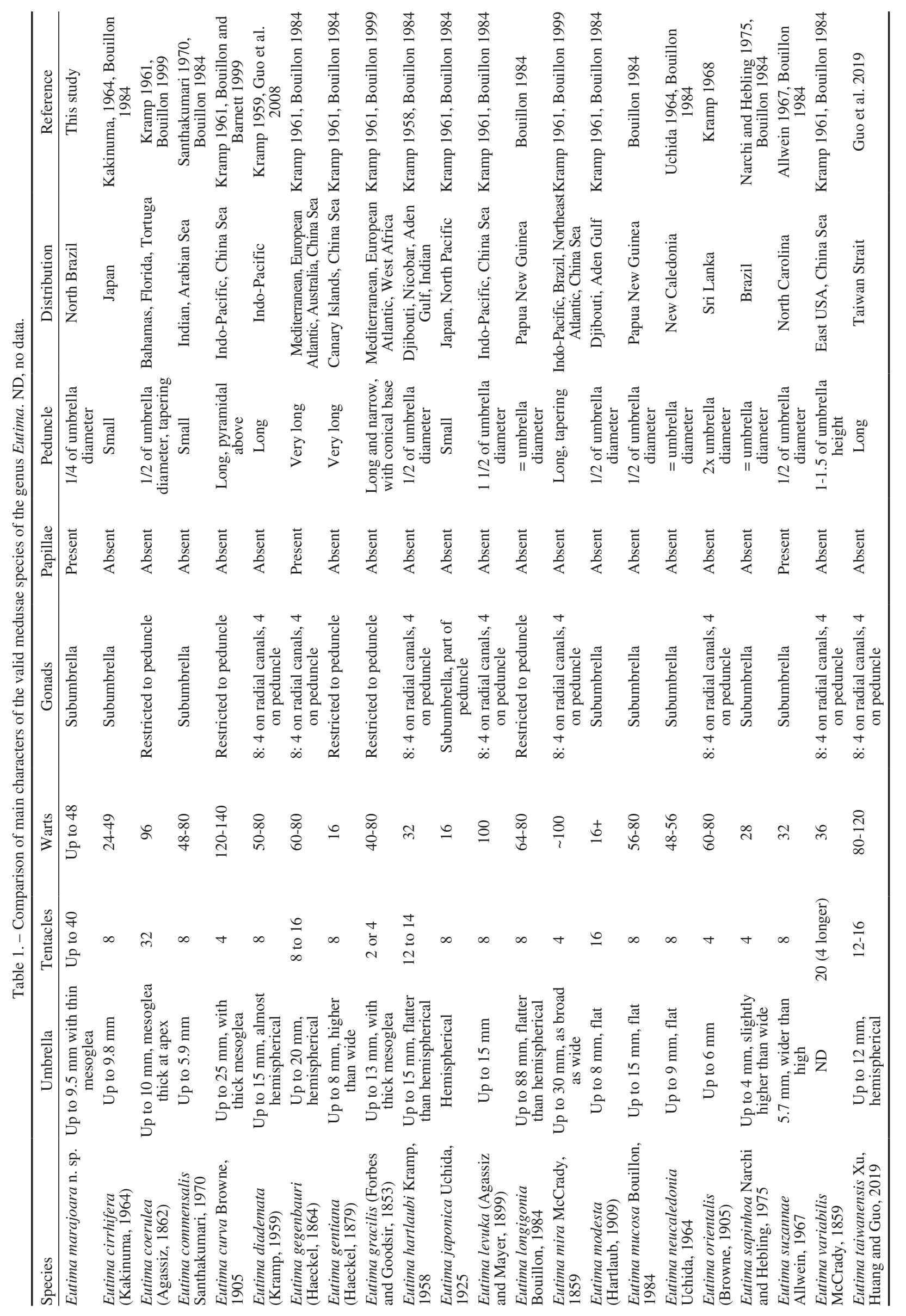


with tentacles and from Eutimalphes Haeckel, 1879, Eutonina Hartlaub, 1897 and Neotima Petersen, 1962 by the presence of lateral cirri on marginal warts and/or tentacles (Bouillon 1999, Bouillon et al. 2006). In the second case, Helgicirrha Hartlaub, 1909 differs from Eirene Eschscholtz, 1829, Tima Eschscholtz, 1829 and Phialopsis Torrey, 1909 by the presence of lateral cirri on tentacular bulbs and from Irenium Haeckel, 1879 by the gonads restricted to the subumbrellar part of the radial canals (Bouillon 1999, Bouillon et al. 2006).

Currently there are 22 valid species described in the genus Eutima and 11 (one with a temporary name) in Helgicirrha in the World Register of Marine Species (Schuchert 2020). Although the general shape of the umbrella, gastric peduncle and manubrium may help with identification, species in the two genera are mainly distinguished by the shape and position of the gonads, the number of marginal structures and presence/ absence of adaxial papillae or excretory pores (Kramp 1961, Bouillon 1984). This is not an easy assignment since most species show a high level of intraspecific variability (Tables 1,2 ), which has not been described in detail, particularly when in juvenile and/or not fully developed specimens.

Specimens from two Eirenidae species were found in a scientific expedition along the Amazonian coast of northern Brazil (Araujo et al. 2017, Tosetto et al. 2019). Species of the family are typically coastal and/ or estuarine, often occurring in high abundance (Canché-Canché and Castellanos-Osorio 2005, MoralesRamírez and Nowaczyk 2006, Mediseh et al. 2017). This aspect, associated with the high feeding rates of pelagic cnidarians (Hays et al. 2018), may place them as significant predators in these environments. The specimens found clearly belonged to the genera Eutima and Helgicirrha because of the characteristics explained above, but did not fit in any of the currently known species. Thus, the objective of this work is to describe Eutima marajoara n. sp. and Helgicirrha angelicae $\mathrm{n}$. sp. In addition, the main characteristics of all species described in both genera are compiled and compared (Tables 1, 2).

\section{MATERIALS AND METHODS}

Specimens were obtained from samples collected in October 2012 at Marajó Bay and along the Amazonian coast, northern Brazil (Fig. 1), with oblique hauls from near bottom to the surface, using a Bongo net with 120 and $300 \mu \mathrm{m}$ mesh and 0.3 and $0.6 \mathrm{~m}$ mouth opening, respectively. The material was fixed with $4 \%$ formaldehyde buffered with sodium tetraborate $\left(0.5 \mathrm{~g} \mathrm{l}^{-1}\right)$. The type material was deposited at the cnidarian collection of the Museu de Zoologia da Universidade de São Paulo (MZUSP), with additional paratypes deposited at the Coleção de Invertabrados Paulo Young from Universidade Federal da Paraíba (CIPY). All applicable international, national and institutional guidelines for the care and use of animals were followed.

In the laboratory, specimens were measured and the number of marginal structures per quadrant was counted under an optical microscope. We considered



Fig. 1. - Sample sites for Eutima marajoara n. sp. (circles) and Helgicirrha angelicae n. sp. (diamond) along the Amazonian coast. "H" indicates holotype locality.

each quadrant separately in order to test for individual variability and to alleviate the problem that some specimens had quadrants with parts of the margin damaged and structures missing. Relationships between umbrella diameter and number and ratio of marginal structures were modelled with linear regressions with Statsoft Statistica 10 software.

\section{RESULTS}

Class Hydrozoa Owen, 1843

Subclass Hydroidolina Collins, 2000

Order Leptothecata Cornelius, 1992

Family Eirenidae Haeckel, 1879

Genus Eutima McCrady, 1859

Eutima marajoara n. sp. (Fig. 2)

LSID: urn:1sid:zoobank.org:act:DCCA8AE8-EF3C-4054-9ED121BEA922F218

Material examined. $0.034383^{\circ} \mathrm{S}, 47.57213^{\circ} \mathrm{W}$ : 175 specimens (10/14/2012). Holotype: MZUSP 8516 (Umbrella diameter: $8 \mathrm{~mm}$, male, Fig. 2A). Paratypes: MZUSP 8517 ( 75 specimens), MZUSP 8518 (42 specimens), CIPY 1122 (57 specimens).

Etymology. Specimens were collected in the waters of Marajó Bay in northern Brazil. Marajoara refers to the native society that inhabited the area before European occupation and gave name to the bay. 
424 - E.G. Tosetto et al.

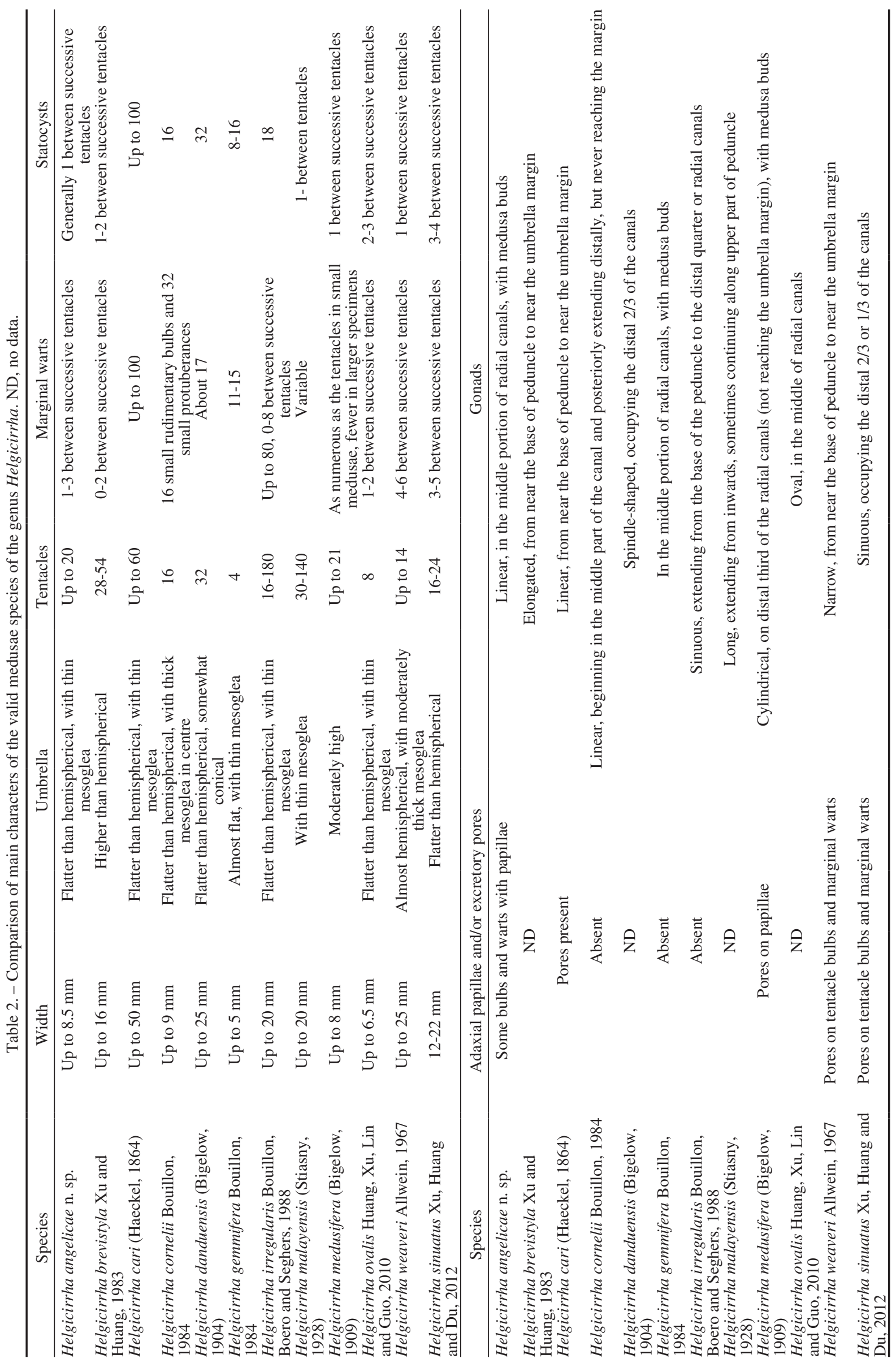



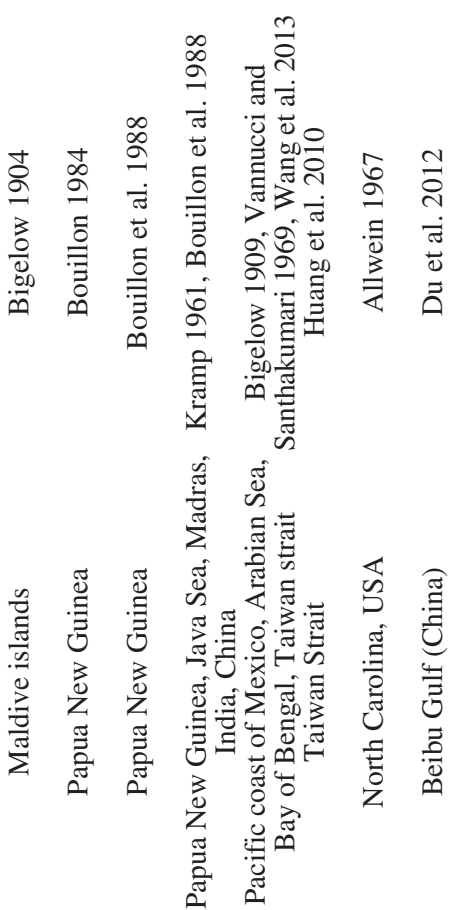

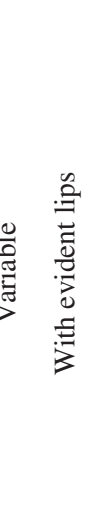

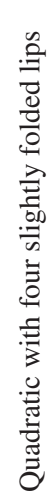

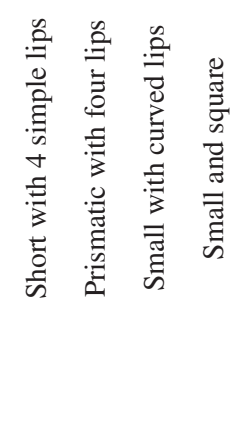

Diagnosis. Eutima medusa with gonads restricted to subumbrella, extending along almost entire length of subumbrellar portion of radial canals. Approximately 32 (up to 40) marginal tentacles with conical bulbs and 32 (up to 48) marginal warts. Some marginal warts and tentacular bulbs with lateral cirri and a few with adaxial papillae.

Description (based on several specimens). Umbrella flat, ranging from 1.5 to $9.2 \mathrm{~mm}$ wide, with thin mesoglea. Manubrium tubular with folded lips. Narrow prismatic gastric peduncle, about $1 / 4$ of umbrella diameter in length. Gonads restricted to subumbrella, linear, extending along almost entire length of subumbrellar portion of radial canals but not connected to ring canal and gastric peduncle (Fig. 2A, B). Approximately 32 (up to 40) marginal tentacles with conical bulbs in adult medusae. Up to 48 marginal warts in different sizes, usually two or three between successive tentacles in small medusae, fewer in larger specimens (as shown by the increase in the ratio between tentacles and warts, Fig. 3). Up to eight statocysts. Some warts and bulbs with lateral cirri (Fig 2C) and a few with adaxial papillae (Fig. 2D). Velum narrow.

Development. Positive significant $(\mathrm{p}<0.05)$ relationships were observed between umbrella diameter and mean number of marginal tentacles, warts, ratio between tentacles and warts and statocysts per umbrella quadrant (Table 3, Fig. 3). Positive values of b coefficient indicate the number of tentacles and warts increases with medusa development (Table 3 ). While smaller specimens $(1.5 \sim 2 \mathrm{~mm})$ had one or two tentacles and two to four warts on each quadrant, individuals of intermediate sizes around $5 \mathrm{~mm}$ had approximately four tentacles and six warts per quadrant (note some individuals had up two 11 warts per quadrant in this stage) and bigger ones ( $~ 9 \mathrm{~mm})$ had up to 10 tentacles and 12 warts per quadrant (Fig. 3). Positive values of b coefficient of tentacles/warts ratio also indicate that warts are relatively more abundant in juveniles (Fig. $3)$. Although the relationship between umbrella diameter and statocyst number was significant ( $p$ value almost 0.05 , very close to the threshold limit of significance), the low value of the b coefficient indicates that the number of statocysts does not increase with medusa development, as was expected because species of Eutima are considered to have a fixed number of statocysts (Table 3, Fig. 3).

Ecological notes. Specimens were found in estuarine waters ( $8 \mathrm{~m}$ bottom depth) of the Marajó Bay, mouth of Pará and Amazon Rivers, at $28.3^{\circ} \mathrm{C}$ temperature and 18.2 salinity throughout the water column.

Genus Helgicirrha Hartlaub, 1909 Helgicirrha angelicae $\mathrm{n}$. $\mathrm{sp}$. (Fig. 4) 

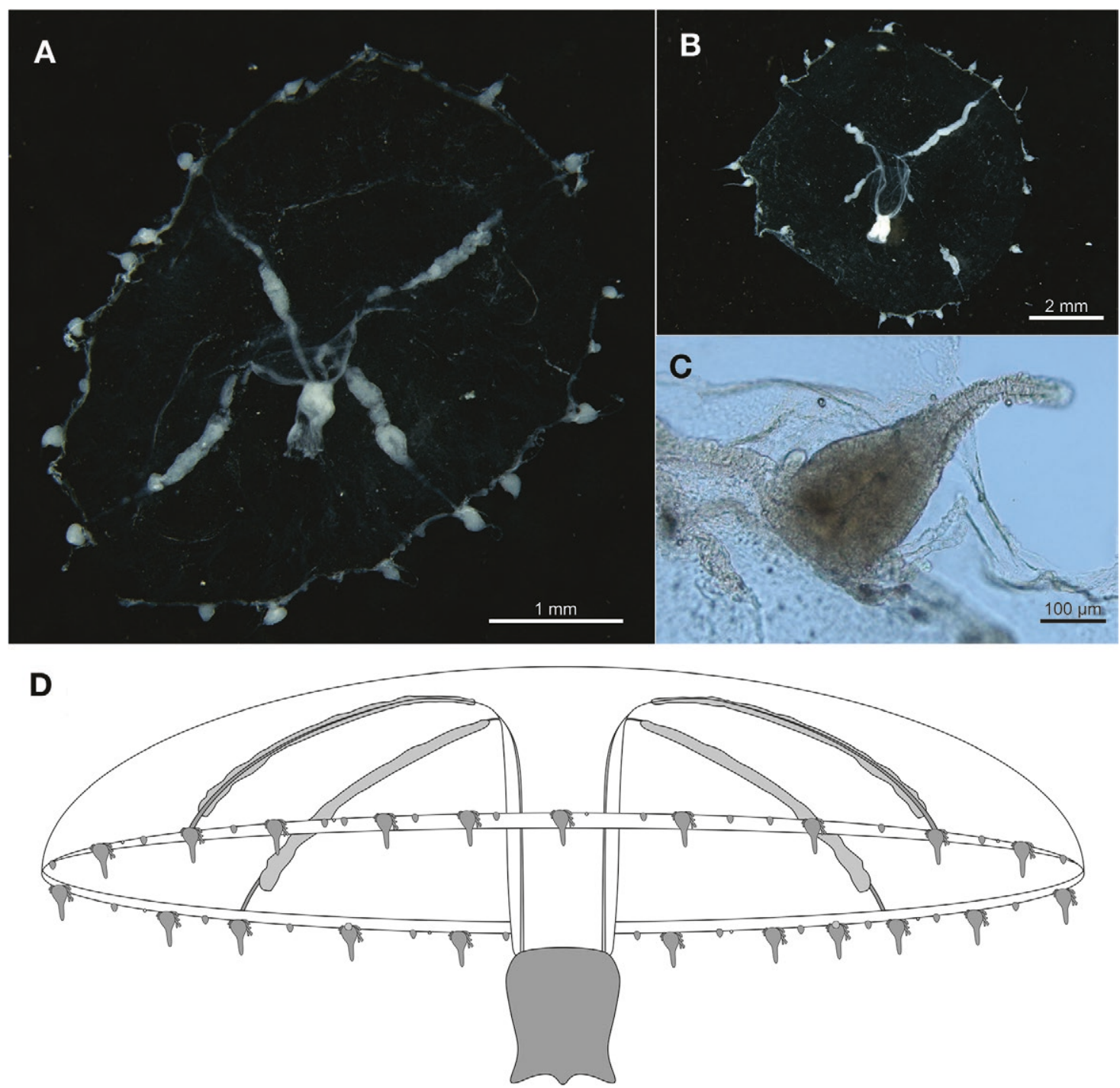

Fig. 2. - Eutima marajoara n. sp. A, oral view of the holotype; B, paratype; C, detail of a tentacular bulb with lateral cirri; D, schematic representation of adult specimen.

Material examined. $4.44^{\circ} \mathrm{N}, 50.896^{\circ} \mathrm{W}: 64$ specimens $(10 / 21 / 2012)$. Holotype: MZUSP 8519 (Umbrella diameter: $6 \mathrm{~mm}$, male, Fig. 4A). Paratypes: MZUSP 8520 (42 specimens), CIPY 1123 (18 specimens). $3.47516^{\circ} \mathrm{N}, 50.16^{\circ} \mathrm{W}: 3$ specimens $(10 / 21 / 2012)$.

Etymology. This species is named after Professor Maria Angélica Haddad, one of the pioneers of hydrozoan studies in Brazil whose passion encouraged generations of students.

Diagnosis. Helgicirrha medusa with gonads on middle portion of radial canals, with medusa buds. Short gastric peduncle. Up to 20 marginal tentacles, some with adaxial papillae. Generally one to three marginal warts and one statocyst between successive tentacles. Lateral cirri on tentacle bulbs and some marginal warts.

Description (based on several specimens). Umbrella flatter than a hemisphere, ranging from 0.8 to $8.5 \mathrm{~mm}$ wide, with thin mesoglea. Small manubrium, mouth with four short simple lips. Short and narrow
Table 3. - Summary and coefficients $(a, b)$ of linear regression relating umbrella diameter and mean number of marginal structures per umbrella quadrant (number of structures $=\mathrm{a}+\mathrm{b} *$ umbrella diameter) in Eutima marajoara n. sp. and Helgicirrha angelicae n. sp. (n, number of specimens analysed; $a$, intercept; $b$, inclination; $p$ values $<0.05$ are considered significant)

\begin{tabular}{lccccc}
\hline & $\mathrm{n}$ & $\mathrm{F}$ & $\mathrm{p}$ & $\mathrm{a}$ & $\mathrm{b}$ \\
\hline Eutima marajoara & & & & & \\
Tentacles & 49 & 197.21 & $<0.0001$ & 0.5 & 0.87 \\
Marginal warts & 49 & 56.14 & $<0.0001$ & 2.62 & 0.76 \\
Tentacles/warts ratio & 49 & 13.03 & $<0.0001$ & 0.51 & 0.05 \\
Statocysts & 47 & 4.07 & 0.0496 & 1.11 & 0.06 \\
Helgicirrha angelicae & & & & & \\
Tentacles & 18 & 152.39 & $<0.0001$ & 0.33 & 0.56 \\
Marginal warts & 17 & 25.69 & $<0.0001$ & -0.1 & 0.87 \\
Tentacles/warts ratio & 17 & 1.76 & 0.21 & 1.08 & -0.05 \\
Statocysts & 15 & 24.77 & $<0.0001$ & 0.3 & 0.45 \\
\hline
\end{tabular}

prismatic gastric peduncle, about 1/4 of umbrella width in length. Linear gonads on middle portion of radial canals, with developing medusa buds (Fig. 4A, C). Up to 20 marginal tentacles with conical bulbs. Up to 28 marginal warts in different sizes, usually one to three between successive tentacles. Lateral cirri on tentacle 
Eutima marajoara
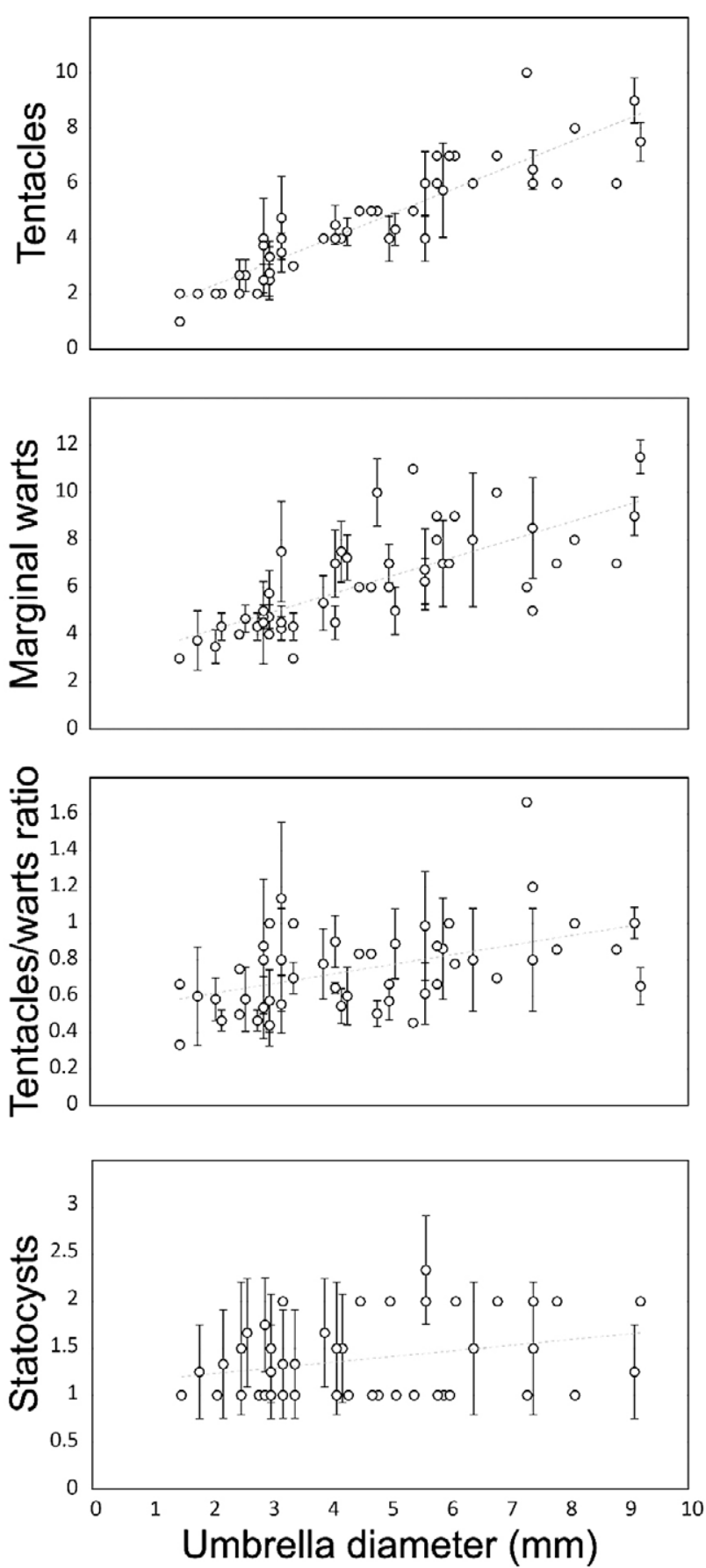

Helgicirrha angelicae
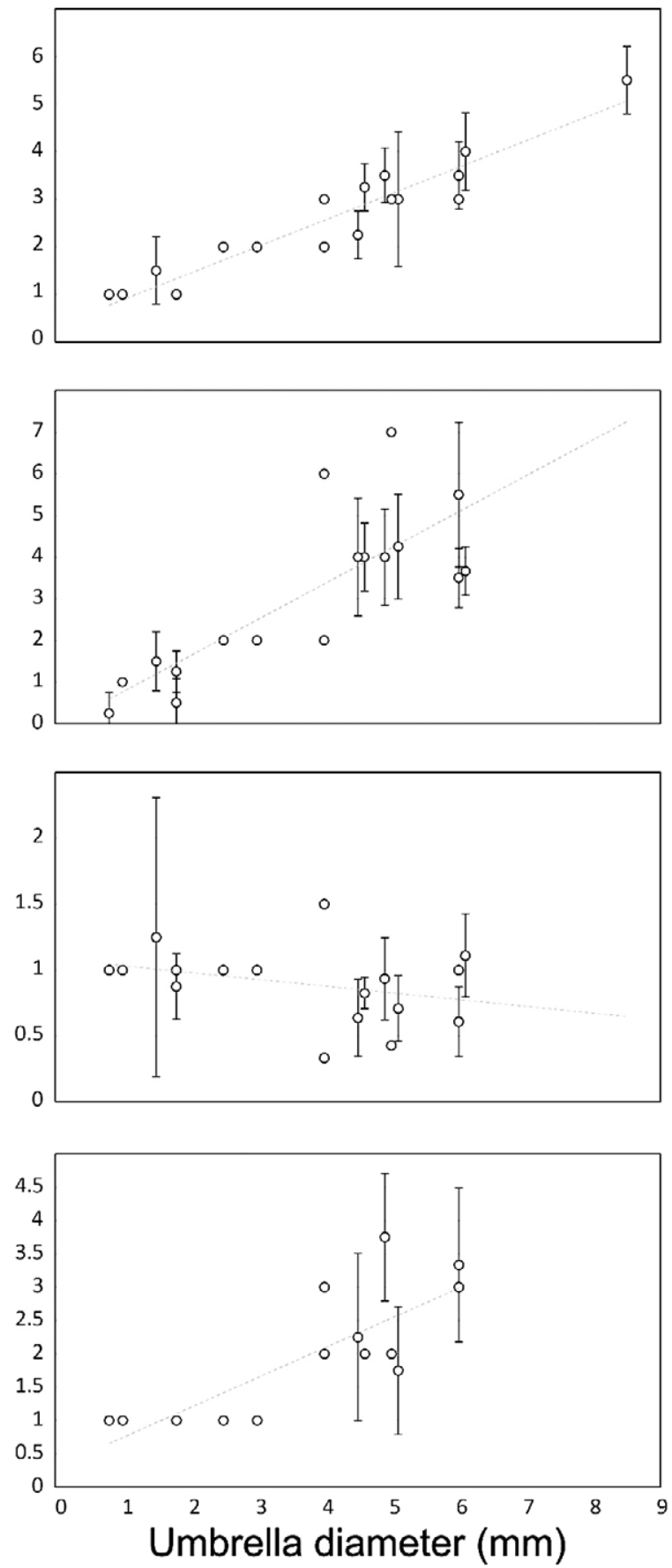

Fig. 3. - Eutima marajoara n. sp. and Helgicirrha angelicae n. sp. relationship between mean number of marginal structures per umbrella quadrant and umbrella diameter. Symbols are mean+SD for each individual; symbols without error bars indicate that data from a single quadrant were available; dotted lines are the result of linear regressions (Table 3).

bulbs and some marginal warts (Fig. 4B). Generally one statocyst between successive tentacles. Some bulbs with adaxial papillae. Velum narrow.

Development. Positive significant $(\mathrm{p}<0.05)$ relationships were observed between umbrella diameter and mean number of marginal tentacles, warts, and statocysts per umbrella quadrant (Table 3, Fig. 3). Positive values of $b$ coefficient indicate that the number of tentacles, warts and statocysts increase with medusa development (Table 3$)$. Smaller specimens $(\sim 1 \mathrm{~mm})$ had one perradial tentacle, one or no interradial warts and one statocyst in each quadrant. Intermediate stages $(\sim 4.5 \mathrm{~mm})$ had around three tentacles, four warts and 2.5 statocysts per quadrant and bigger specimens $(6 \sim 8 \mathrm{~mm})$ had up to six tentacles, seven warts and five statocysts per quadrant (Table 3, Fig. 3). Ratios between tentacles and warts were not significantly correlated with umbrella diameter. 

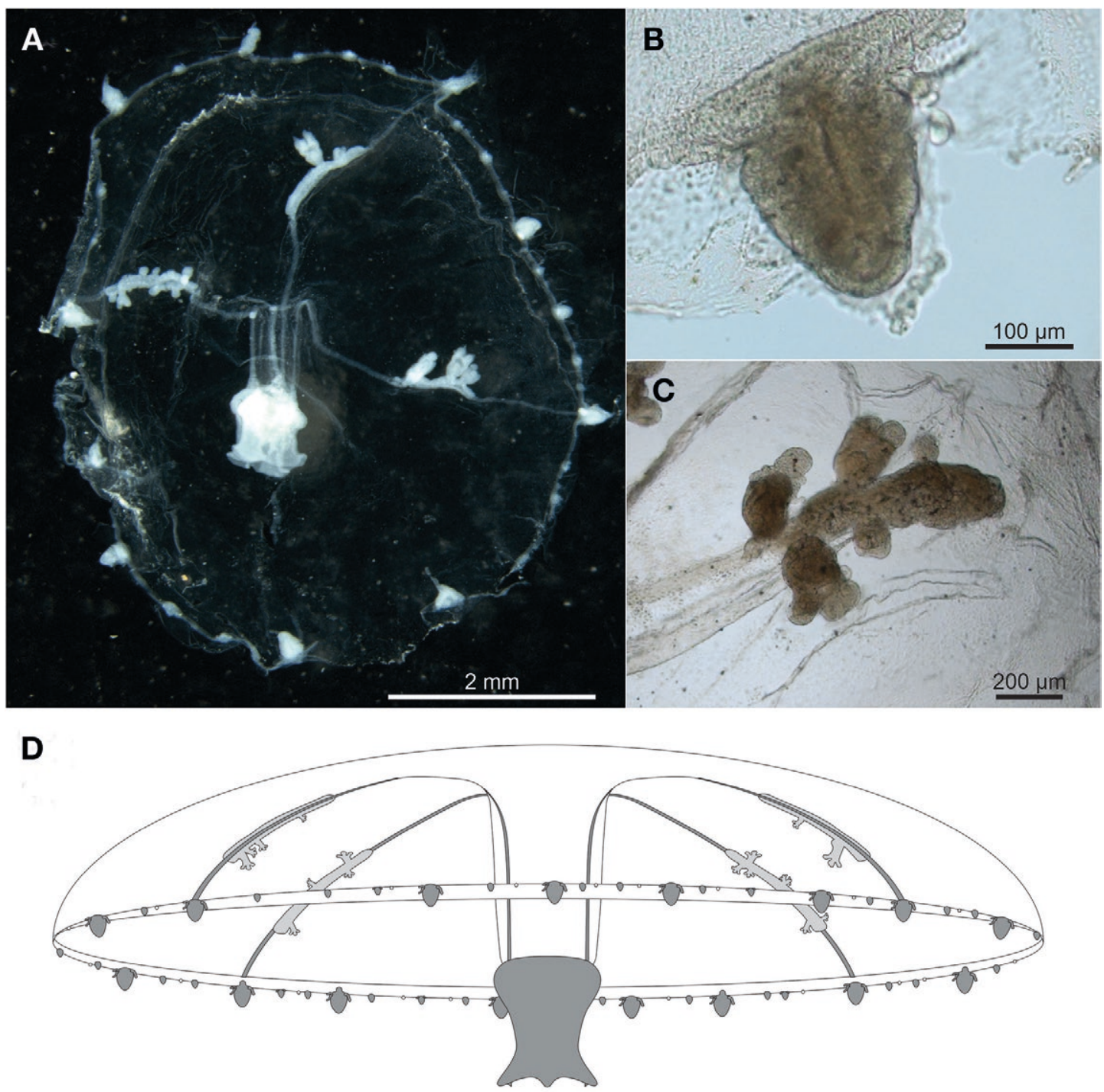

Fig. 4. - Helgicirrha angelicae n. sp. A, oral view of the holotype; B, detail of the tentacular bulb with lateral cirri; C, detail of a gonad with medusa buds; D, schematic representation of adult specimen.

Ecological notes. Specimens were found in neritic waters over a reef system (30-65 m bottom depth) under the influence of the Amazon River plume with water column temperature ranging from $24.9^{\circ} \mathrm{C}$ to $27.9^{\circ} \mathrm{C}$ and salinity from 31.1 to 36.3 .

\section{DISCUSSION}

Genera of the family Eirenidae are mainly distinguished by the number of statocysts, the position of the gonads and the presence of marginal structures such as, cirri, warts and adaxial papillae (Bouillon et al. 2006). Eutima and Helgicirrha species always have lateral cirri on the tentacle bulbs and/or marginal warts, and some species of both genera have adaxial papillae and gonads restricted to the subumbrella (Bouillon 1984, Bouillon et al. 2006, Schuchert 2017), as do the specimens found in this study. However, Eutima species have eight statocysts (rarely 12) in adult medusae and Helgicirrha always has more than eight and up to an indefinite number (Bouillon 1984, Bouillon et al.
2006). The number of statocysts is the main character distinguishing the two genera (the absence of excretory pores in Eutima is controversial and will be discussed later) and was used to assign the genera of the two species discussed herein. However, when the medusae development was observed, smaller specimens of both had fewer statocysts (Fig. 3C, G), and observations based on these individuals, associated with the fragility of these organisms (marginal structures are frequently lost in net trawls and/or formalin fixation), could lead to misidentification. These observations reinforce the need to examine fully developed specimens and to characterize their ontogenetic development for accurate identification and to elucidate the taxonomy of complex families such as Eirenidae.

Distinctive characters of Eutima marajoara $\mathrm{n}$. sp. are the gonads restricted to the subumbrella, the adaxial papillae on few marginal warts and/or tentacle bulbs and the large number of marginal tentacles. Among the other seven species described in the genus with gonads restricted to the subumbrella, only Eutima 
suzannae Allwein, 1967 also have adaxial papillae (Table 1). However, unlike in E. marajoara n. sp., in $E$. suzannae papillae are restricted to the marginal warts. Other differences are the longer gastric peduncle in $E$. suzannae and the number of tentacles and marginal warts. While E. marajoara have up to 40 (usually 32 in adults) tentacles and 1 to 3 warts between successive tentacles, E. suzannae have only eight tentacles and four warts between them (Allwein 1967). Moreover, the high number of tentacles in E. marajoara n. sp. is noteworthy. While most species in the genus have eight or four tentacles, only E. marajoara n. sp. and Eutima coerulea (Agassiz, 1862) have more than 20. However, in E. coerulea the gonads are restricted to the peduncle, unlike in our specimens (Table 1).

The original description of Eutima included species without papillae (McCrady 1859). A few years later Octorchis Haeckel, 1864 was described (Haeckel 1864), differing from Eutima mainly in the presence of adaxial papillae in Octorchis and their absence in Euti$m a$ (e.g. Russell 1953). Subsequent studies considered both as subgenera within the genus Eutima (Kramp 1961, Bouillon 1984). Currently the subgenus rank fell out of use and all species previously considered $O c$ torchis are included within Eutima (Schuchert 2020), which now encompasses eirenids with eight statocysts and lateral cirri, with or without papillae (Kramp 1961, Bouillon 1984, Schuchert 2020; Table 1). One open question is whether these papillae do possess an excretory pore, which would be necessary to regard them as excretory papillae (as mentioned in recent diagnoses, e.g. Bouillon and Boero 2000, Bouillon et al. 2006), because this is hard to verify and requires detailed histological observations (Schuchert 2017).

Only the hydroid stage and newly released medusa are known in Eutima ostrearum (Mattox and Crowell, 1951). Hydroids of this species were found inhabiting the mantle cavity of oysters in an estuarine system in Puerto Rico (Mattox and Crowell 1951). Due to the close geographic location and similar habitat (e.g. estuarine waters), E. marajoara n. sp. could be the adult medusa of E. ostrearum. Future studies based on molecular data from both localities and on hydroids inhabiting the Marajó Bay are necessary to answer this question. However, newly released E. ostrearum of up to $3 \mathrm{~mm}$ displayed no lateral cirri and had no sign of a gastric peduncle (Mattox and Crowell 1951). Although these characters may develop later in the medusa ontogeny, they differ from our smaller specimens within the same size range $(1.5-3 \mathrm{~mm})$, which already had lateral cirri and a small but clearly visible peduncle. These differences suggest they are different species.

Specimens of Helgicirrha angelicae n. sp. have linear gonads located in the middle portion of the radial canals. Shape and position of gonads are important characters for the taxonomy of Helgicirrha and other Eirenidae medusae (e.g. Bouillon 1984, Bouillon et al. 1988, Huang et al. 2010). Indeed, the gonadal position was helpful to distinguish the present specimens from Helgicirrha brevistyla Xu and Huang, 1983, Helgicirrha cari (Haeckel, 1864), Helgicirrha danduensis (Bigelow, 1904), Helgicirrha irregularis Bouillon, Boero and Seghers, 1988, Helgicirrha malayensis (Stiasny, 1928), Helgicirrha medusifera (Bigelow, 1909), Helgicirrha weaveri Allwein, 1967 and Helgicirrha sinuatus $\mathrm{Xu}$, Huang and $\mathrm{Du}, 2012$, which have gonads in other positions than the middle portion of the radial canals (see Table 2 and reference therein). Among the remaining species, Helgicirrha cornelii Bouillon, 1984, Helgicirrha gemmifera Bouillon, 1984 and Helgicirrha ovalis Huang, Xu, Lin and Guo, 2010, unlike our specimens, do not have adaxial papillae either on the tentacular bulbs or on the marginal warts. In addition, they are distinct from the current specimens in the lower number of tentacles and shape of the gonads in the case of $H$. ovalis and $H$. cornelii (Table 2). Unlike in Eutima, species of Helgicirrha may or may not have excretory pores either on papillae (e.g. H. medusifera) or directly on the bulbs and warts (e.g. H. weaveri); however, pores were not observed on $H$. angelicae papillae.

The presence of medusa buds on every gonad of all adult specimens of $H$. angelicae n. sp. is also an outstanding character that is useful to distinguish it from all other species but $H$. gemmifera and $H$. medusifera. As cited above, the former is quite different from $H$. angelicae $\mathrm{n}$. sp. However, $H$. medusifera differs mainly in the position of the gonads, which are located on the distal third of the radial canals (Table 2), while in our specimens they are in the middle (Fig. 3). The large number of specimens found in our samples allowed us to observe the complete development of medusae, and in any case the gonads approached the ring canal or were even located on the distal region of the radial canals, while in $H$. medusifera they are clearly very close to it (Bigelow 1909). The different geographical distribution of the two species (the western Atlantic and the eastern Pacific) also argues against the possibility that they are morphological variations of the same species. Furthermore, in adult medusae of $H$. medusifera most marginal warts turn into developed bulbs with tentacles and few warts are present (Bigelow 1909), and this is not the case for $H$. angelicae n. sp. because the number of warts increased with medusa development in similar proportion to the tentacles (Fig. 3). Future studies based on molecular data of both species could completely elucidate this question.

Among the 177 samples analysed, covering the northern Brazilian continental shelf and adjacent equatorial Atlantic oceanic waters (see Fig. 1 from Tosetto et al. 2019), both species had very restricted distributions. Currently, E. marajoara n. sp. has been found only in the waters of Marajó Bay, an estuarine environment (18.2 salinity) located in the mouth of the Pará and Amazon rivers, and is perhaps an endemic species to the area. $H$. angelicae $\mathrm{n}$. $\mathrm{sp}$. was restricted to coastal waters under the influence of the Amazon River plume. Knowledge on the zooplankton community inhabiting waters of the Amazonian coast is still scarce (Boltovskoy and Valentin 2018). Recently, this unique ecosystem has attracted attention from scientific and public society because of the presence of hard-bottom reefs (Moura et al. 2016) and oil exploitation in the area (Silva Junior and Magrini 2014), which may lead 
to significant impacts and losses in the rich, but still poorly known, biodiversity in the area.

\section{ACKNOWLEDGEMENTS}

We are grateful to the Brazilian National Institute of Science and Technology for Tropical Marine Environments, the Brazilian Research Network on Global Climate Change and European Integrated CARBOCHANGE for funding the Camadas Finas III survey for their support and to all the scientific team on board. We thank the CNPq (Brazilian National Council for Scientific and Technological Development), which provided a PhD scholarship to E.G.T. (grant 140897/2017-8) and a Research Scholarship to S.N.L.

\section{REFERENCES}

Allwein J. 1967. North American Hydromedusae from Beaufort, North Carolinae. Vidensk. Meddel. Dansk Naturhist. Foren. 130: 117-136.

Araujo M., Noriega C., Hounsou-gbo G.A., et al. 2017. A Synoptic Assessment of the Amazon River-Ocean Continuum during Boreal Autumn: From Physics to Plankton Communities and Carbon Flux. Front. Microbiol. 8: 1-18. https://doi.org/10.3389/fmicb.2017.01358

Bigelow H.B. 1904. Medusae from the Maldive Islands. Bull. Mus. Comp. Zool. 39: 245-269.

Bigelow H.B. 1909. The Medusae. Reports on the scientific results of the expedition to the eastern tropical pacific, in charge of Alexander Agassiz, by the U. S. Fish Commission steamer "Albatross" from October, 1904, to March, 1905. XVI. Mem. Mus. Comp. Zool. 37: 1-243.

Boltovskoy D., Valentin J.L. 2018. Overview of the History of Biological Oceanography in the Southwestern Atlantic, with Emphasis on Plankton. In: Hoffmeyer M.S., Sabatini M.E., et al. (eds). Plankton Ecology of the Southwestern Atlantic. Springer Science+Business Media, New York, pp. 3-34. https://doi.org/10.1007/978-3-319-77869-3 1

Bouillon J. 1984. Hydroméduses de la Mer de Bismark (Papouasie Nouvelle-Guinée. Partie IV: Leptomedusae (Hydrozoa-Cnidaria). Indo-Malayan Zool. 1: 25-112.

Bouillon J. 1999. Hydromedusae. In: Boltovskoy D. (ed.), South Atlantic zooplankton. Backhuys Publishers, Leiden. pp. 424-512.

Bouillon J., Barnett T.J. 1999. The marine fauna of New Zealand: Hydromedusae (Cnidaria: Hydrozoa). National Institute of Water and Atmospheric Research (NIWA), Wellington, $136 \mathrm{pp}$.

Bouillon J., Boero F. 2000. Synopsis of the families and genera of the hydromedusae of the world, with a list of the worldwide species. Thalassia Salent. 24: 47-296.

Bouillon J., Gravili C., Pagès F., et al. 2006. An introduction to Hydrozoa. Muséum national d'Histoire naturelle, Paris, $591 \mathrm{pp}$

Bouillon J., Medel M.D., Pagès F., et al. 2004. Fauna of the Mediterranean Hydrozoa. Sci. Mar. 68: 5-438. https://doi.org/10.3989/scimar.2004.68s25

Bouillon J., Seghers G., Boero F. 1988. Notes additionnelles sur les méduses de Papouasie Nouvelle-Guinée (Hydrozoa, Cnidaria). III. Indo-Malayan Zool. 5: 225-253.

Canché-Canché V.E., Castellanos-Osorio I. 2005. Medusas (Cnidaria) de la Bahía de la Ascensión, Quintana Roo, México (1997). Hidrobiológica 15: 65-72.

Du F., Xu Z., Huang J., et al. 2012. Studies on the medusae (Cnidaria) from the Beibu gulf in the Northern South China Sea, with description of three new species. Acta Zootaxon. Sinica 37: 506-519.

Guo D., Xu Z., Huang J. 2008. Two new species of Eirenidae from the coast of southeast China. Acta Oceanol. Sin. 27: 61-66.

Guo D., Xu Z., Huang J., et al. 2019. Two new hydrozoan species from the Taiwan Strait, China (Cnidaria: Hydrozoa: Leptothecata). Zool. System. 43: 185-190.

Haeckel E. 1864. Beschreibung neuer Craspedoter Medusen aus dem Golfe von Nizza. Jenaer Zeitschrift für Medizin und Natur- wissenschaften 1: 326-342.

Hays G.C., Doyle T.K., Houghton J.D.R. 2018. A Paradigm Shift in the Trophic Importance of Jellyfish? Trends Ecol. Evol. 33: 874-884. https://doi.org/10.1016/j.tree.2018.09.001

Huang J., Xu Z., Lin M., et al. 2010. Two new species of Leptomedusae from Taiwan Strait and its adjacent waters, China. J. Xiamen Univ. (Natural Science) 49: 87-90

Kakinuma Y. 1964. A new commensal hydrozoan, Eugymanthea cirrhifera n. sp. from Hachinohe. Bul. Mar. Biol. Stn. Asamushi 12: $51-57$

Kramp P.L. 1958. Hydromedusae in the Indian museum. Rec. Ind. Mus. 53: 339-376.

Kramp P.L. 1959. Some new and little-known Indo-Pacific medusae. Videnskabelige Meddelelser fra Dansk Naturhistorisk Forening 121: 223-259.

Kramp P.L. 1961. Synopsis of the medusae of the World. J. Mar. Biol. Assoc. U.K. 40: 1-469. https://doi.org/10.1017/S0025315400007347

Kramp P.L. 1968. The Hydromedusae of the Pacific and Indian oceans. Sections II and III. Carlsberg Foundation, Copenhagen, $200 \mathrm{pp}$.

Mattox N.T., Crowell S. 1951. A new commensal hydroid of the mantle cavity of an oyster. The Biol. Bull. 101: 162-170. https://doi.org/10.2307/1538383

McCrady J. 1859. Gymnopthalmata of Charleston Harbor. Proc. Elliott Soc. Nat. Hist. 1: 103-221.

Mediseh S.D., Koochaknejad E., Dehmourdi L.M., et al. 2017. Jellyfish of Khuzestan coastal waters and their impact on fish larvae populations. Iran. J. Fish. Sci. 16: 422-430.

Morales-Ramírez A., Nowaczyk J. 2006. El zooplancton gelatinoso del Golfo Dulce, Pacífico de Costa Rica, durante la transición de la estación lluviosa a la seca 1997-1998. Rev. Biol. Trop. 54: 201-223.

Moura R.L., Amado-Filho G.M., Moraes F.C., et al. 2016. An extensive reef system at the Amazon River mouth. Sci. Adv. 2: $1-11$. https://doi.org/10.1126/sciadv.1501252

Narchi W., Hebling N.J. 1975. The life cycle of the commensal hydromedusa Eutima sapinhoa n. sp. Mar. Biol. 30: 73-78. https://doi.org/10.1007/BF00393755

Pagès F., Gili J.-M., Bouillon J. 1992. Medusae (Hydrozoa, Scyphozoa, Cubozoa) of the Benguela Current (Southeastern Atlantic). Sci. Mar. 56(Suppl. 1): 1-64.

Russell F.S. 1953. The Medusae of the British Isles. Cambridge University Press, London, $530 \mathrm{pp}$.

Santhakumari V. 1970. The life cycle of Eutima commensalis n. sp. (Eutimidae, Hydromedusae). Mar. Biol. 5: 113-118 https://doi.org/10.1007/BF00352594

Schuchert P. 2017. Systematic notes on some leptomedusa species with a description of Neotima galeai n. spec. (Hydrozoa, Cnidaria). Rev. Suisse Zool. 124: 351-375.

Schuchert P. 2020. World Hydrozoa Database. Available from: http://www.marinespecies.org

Silva Junior O.M., Magrini A. 2014. Exploração de Hidrocarbonetos na Foz do Rio Amazonas: Perspectivas de Impactos Ambietais no Âmbito das Áreas Ofertadas na 11o Rodada de Licitacões da Agência Nacional do Petroléo. Rev. Geoamazônia 2: 146-158. https://doi.org/10.17551/2358-1778/geoamazonia. v2n4p 146-158

Tosetto E.G., Neumann-Leitão S., Nogueira Júnior M. 2019. Sampling planktonic cnidarians with paired nets: Implications of mesh size on community structure and abundance. Estuar. Coast. Shelf Sci. 220: 48-53 https://doi.org/10.1016/j.ecss.2019.02.027

Uchida T. 1964. Some medusae from New Caledonia. Publ. SMBL. 12: $109-112$. https://doi.org/10.5134/175348

Vannucci M., Santhakumari V. 1969. New records of hydromedusae from the shelf area off the Kerala Coast. J. Mar. Biol. Ass. India 11: 40-43.

Wang C., Huang J., Xu Z., et al. 2013. One new species and one new record species of Eirenidae form the Taiwan Strait. Acta Zootaxonomica Sin. 38: 762-764.

Xu Z., Huang J. 1983. On the Hydromedusae, Siphonophora, Scyphomedusae and Ctenophora from the Jiulong River Estuary of Fujian, China. Taiwan Strait 2: 99-110. 